\title{
Ermeni Diasporası ve Ermenistan: Siyasi, Ekonomik ve Dini İliş̧kiler
}

\author{
Armenian Diaspora and Armenia: Political, Economic and Religous \\ Relations \\ Özer ÖZOCAK*
}

$\ddot{O z}$

Ermeniler, insanlık tarihinin farklı dönemlerinde yaşamakta oldukları yerlerden çeşitli nedenlerle göç ettiler. Yeni yaşam alanlarında, Ermeni kimliğini yaşatma arzuları ile soykıım iddialarını hafızalarda diri tutmak maksadıyla çeşitli heykellerin açılış törenleri, anmalar ve toplantılar düzenlediler. Diaspora Ermenileri diğer unsurları ile Karabağ sorununda olduğu gibi farklı meselelerde siyaseten birlikte hareket ettiler. Ermenistan'ın kalkındırılması, 1988 depremi özelinde afetin yol açtı̆̆ yaraların sarılması ve Yukarı Karabağ sorununun Ermenistan'ın arzuladığı biçimde çözülmesi için maddi destekte bulundular. Ermenistan'la dini bakımdan da irtibatlar kurdular. Bu kapsamda çalı̧mamızda, Diaspora Ermenilerinin Ermenistan ile siyasi, ekonomik ve dini ilişkileri üzerinde durulacaktır.

Anahtar Kelimeler: Ermeni Diasporası, Ermenistan, Siyasi İlişkiler, Ekonomik İlişkiler ve Dini İlişkiler.

\begin{abstract}
Armenians migrated from the places they lived in different periods of human history for various reasons. In their new living spaces, they organized opening ceremonies, commemorations and meetings for various statues in order to keep the Armenian identity alive and to keep the genocide alive in memory. Diaspora Armenians acted politically together with their other elements on different issues, such as the Karabakh issue. They provided financial support for the development of Armenia, the healing of the wounds caused by the disaster, especially the 1988 earthquake, and the resolution of the Nagorno-Karabakh conflict as Armenia desired. They also established religious relations with Armenia. In this context, our study will focus on the political, economic and religious relations of Diaspora Armenians with Armenia.
\end{abstract}

Keywords: Armenian Diaspora, Armenia, Political Relations, Economical Relations and Religious Relations.

\section{Giriş}

Gevork Emin 'We (Biz)' adlı şiirinde, Ermenilerin bir araya getirilmeleri zor olan boncuk taneleri gibi dağıldıklarına değinmektedir. Diaspora milletlerinden biri olarak farklı yerlerde yaşadıklarını dile getirmektedir (Emin, 2014). Şairin dizelerine de yansıyan bu durum, Ermenilerin diaspora milletleri kategorisine ne zaman dahil oldukları sorusunun da kendiliğinden belirmesine yol açmaktadır. Örneğin, İstanbul'un fethi sonrasında Anadolu ve İran topraklarının yanı sıra Kırım'dan Ermenilerin şehre göç etmeleri başta ticari kaygılar olmak üzere çeşitli nedenlerle Ermenilerin bilinen dünyaya yayıldıklarını ortaya koymaktadır (Barsoumian, 2013, s. 23). Ermenilerin farklı yerlere dağılmışlıkları, ilk Ermenice kitabın 1511'de Venedik'te yayımlanması ve ilk Ermenice matbaanın 1565'te aynı şehirde kurulmasıyla da kendisini göstermektedir (Panossian, 1998, s. 149-196). Diğer taraftan Ermenilerin diaspora milletlerinden biri olmalarında bazı tarihi dönemlerin ve kararların çok büyük önemi vardır. Bu noktada Ermeni tarihçilere göre, Şah Abbas (1585-1628) dönemi ve sonrası idarecilerinin siyasetleri öne çıkanlardandır. I. Abbas döneminde İran kuvvetleri Osmanlı Devleti karşısında geri çekilirken Ermenilere ait tüm manastırları, kiliseleri, evleri yakmışlar ve Ermenileri İran topraklarına yerleştirdiler (Basmacıyan, 2009, s. 28-29). İran topraklarının ticari faaliyetler açısından uygunluğu da Ermenilerin uzak yerlerle temaslarına ve göçlerine etkide bulundu (Aslanian, 2011, s. 2-3). I. Abbas dönemi sonrasında ülke idarecilerinin uyguladıkları siyaset Afganistan, Belucistan, Çin, Birmanya, Java, Sumatra ve Filipin adalarına kadar geniş bir alana Ermeni göçlerinin gerçekleşmesine neden oldu (Basmaciyan, 2009, s. 28-29).

I. Dünya Savaşı yılları öncesinde yaşananlar ve savaş sırasında alınan Sevk ve İskan Kanunu ise, Ermenilerin önemli diaspora milletlerinden olmalarında büyük tesiri olan bir

*Arş. Gör. Dr., Amasya Üniversitesi, Fen Edebiyat Fakültesi, Tarih Bölümü, ozerozocak38@gmail.com

Özocak, Ö., (2022). Ermeni Diasporası ve Ermenistan: Siyasi, Ekonomik ve Dini İlişkiler, Asia Minor Studies, Cilt 10 Say1 1, 63-74 Gönderim tarihi: 13-10-2021, Kabul tarihi: 28-01-2022.

Araştırma Makalesi. 
sürecin yaşanmasına yol açtı. Osmanlı Devleti'nin son dönemlerinde çoğunlukla bireysel nitelikteki göçler belirtilen kararla kitlesel bir hale dönüştü. Sevk ve İskan Kanunu'nun kapsamına girenler, Osmanlı Devleti'nin güneydeki topraklarına yerleştirilseler de çeşitli yollarla farklı yerlere dağıldılar. Amerika'da yaşayan Ermenilerin 1920'lerde beyaz olduklarını yasal olarak tescil ettirme ihtiyacı hissetmelerini de doğuran dışlanmışlıkları, sevk ve iskan kararı ve uygulamasına yüklenen anlamların kapsamını daha da genişlettiler. Süreç içinde sözde soykırım kararının fiiliyata geçirilmesi için alındığı savunulan Sevk ve İskan kararı, Ermenilerce yaşanılan zorlukların asıl gerekçesi olarak görülmeye başlandı (Alajaji, 2019, s. 66-67). Osmanlı topraklarında 1908 yılında gerçekleşen Adana olayları gibi çeşitli hadiselerle bir oluş sırası içinde aktarılarak Osmanlı Devleti'nin son döneminde asimetrik bir biçimde soykırım politikası takip ettiği iddia edildi. Böylece Türk düşmanlığı üzerine bina edilen bir kimlik oluşturulmaya çalışıldı (Özocak, 2014, s. 3483-3493). Bu kimlik tesisi süreci de elbette yeni yaşam sahalarında asimilasyon tehdidi karşısında Ermeni kimliğiyle varlıklarını sürdürebilme kaygıları ile doğrudan ilintilidir; çünkü Osmanlı topraklarından göç eden Ermeni diasporası mensupları Ermeni kimliğini, kültürünü ve bilincini yaşatma noktasında özen gösterseler de yeni nesillerin yerleşilen ülkenin dil ve kültürünü büyük oranda benimsemeleri ilk kuşakların duydukları kaygıları artırmaktadır (Bakalian, 1993, s. 22). Bu duruma bir çözüm olarak Diaspora Ermenileri, Ermeni olma bilincinin artması için Ermeniler arasında yaygın olarak kullanılan 'Türk Türk'tür' deyimi çerçevesinde Türkiye ve Türk milleti karşıtı bir düşünce ile hareket etmektedirler (Tuncel, 2015, s. 90). Anavatan duygusu merkezli, Türkiye aleyhinde propagandayı ve Türkiye'nin uluslararası camiada yalnızlaşmasını temin maksadıyla lobi faaliyetlerine hız kazandırdılar (Alajaji, 2019, s. 87).

Ermeni diasporasının varlığını sürdürmek için bir araç olarak kullanılan kurgular, efsaneleşen milli hadiseler ve milli kahramanlar gibi unsurlarla beslenmektedir. Bu noktada Krasnodar Olayını, Antranik Ozanyan'ı ve Avedis Nazarbekyan'ı anmak için düzenlenen törenler örnek olarak gösterilebilir. Bu kapsamda Güney Amerika'da Ermeni cemaatinin varlığını sürdürdüğü Brezilya'daki Ermeniler, 20 Mayıs 1920'de Ermeniler için son derece önemli olan Antranik, Avedis ve diğer Ermeni askerleri için 'Armenia İndependente (Bağımsız Ermenistan)' adlı bir yayın yaptılar (U.upnufituudu' 1948:68). Brezilya'daki Ermeni cemaati temsilcilerinin oluşturduğu Ermeni Koloni Birliği, 10 Ekim 1927'de Antranik'i anmak için kilisenin bahçesinde bir anma programı organize edildi. Bu anma programını aktaran Hayrenik Gazetesi, 'Büyük Adam' olarak adlandırdıkları Antranik Ozanyan'la ilgili anma törenlerinin her sene daha da güçlenerek devam edeceğine yer verildi. Gazete, anma merasimi sırasında 'Karanlık Bulutlar' adında bir ilahi başta olmak üzere çok sayıda ilahinin okunduğuna, Prof. Benyamin Kayzakyan Antranik'in vatanseverliği ve milleti için cesurca mücadelesinden bahsettiğine, Yönetim Kurulu üyesi Hayk Vartanyan'ın da Antranik'in hayatından bir bölümü aktarıp Antranik'in Türklere karşı verdiği mücadelenin üzerinde durduğuna değinmektedir

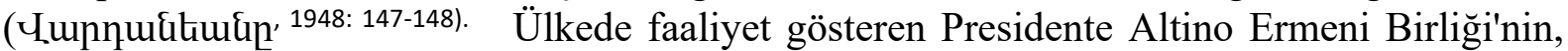
yaptığı ilk etkinlik de Antranik'i anma merasimidir. Merasime, President Altino'da yaşayan

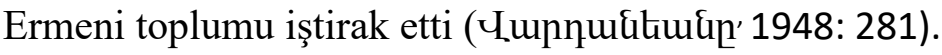

Ermeni diasporasının ve Ermenistan idarecilerinin zihninde, Ermenistan'ın sınırlarının bugünkü sınırlarından farklı olduğunu da belirtmek gerekmektedir. Bunlara göre, Ermenistan'ın doğal sınırlarının bir kısmı, Türkiye Cumhuriyeti'nin işgali altındadır. Zira Ermenistan Cumhurbaşkanlığ 1 forsunda (Ermenistan Cumhurbaşkanlığ Futbol Federasyonu (Ermenistan Futbol Federasyonu Resmi İnternet Sitesi, ${ }^{2021)}$ ve Amerika Ermeni Asamblesi'nin (Armenian Assembly of America (AAA) Internet Sitesi, 2021) ambleminde yanı sira Amerika Ermeni Ulusal Komitesi (Armenian National Committee of America (ANCA) İnternet Sitesi, 2021) sitesi anasayfa resminde olduğu gibi Ağrı Dağı'nın bir simgesi kullanılmaktadır. Ermenistan'daki ve diaspora Ermenilerindeki bu yaklaşım, Ermeni 
topraklarına ilişkinin tasavvurun ülkenin bugünkü sınırlarından farklı olduğunu göstermektedir. $\mathrm{Bu}$ gerçekleri de göz ardı etmeyerek Diaspora Ermenilerinin Ermenistan arasındaki ilişkileri çok sayıda kavram merkezli olarak farklı açılardan incelemek gerekmektedir.

Ermeniler denilince soykırım iddialarından dolayı Türkiye'de yapılan akademik çalışmalarda ve Ermenilerle ilgili tarih yazımında ağırlıklı olarak Osmanlı Devleti'nin son döneminde yaşanan acı olaylara yoğunlaşıldığı görülmektedir. Belirtilen odaklanma ile Ermeni diasporası ve Ermenistan arasındaki ilişkilerin incelenmesi büyük oranda geri plana itildi. Buna karşın Diaspora Ermenilerinin Ermenistan'ın siyasi, ekonomik vs. dış dünya ile kurduğu ve kuracağ 1 her alandaki irtibat noktasında önemli bir işlev gördüğü artık yadsınamaz bir gerçek haline geldi. Özellikle de 2020 yılının sonlarında Yukarı Karabağ anlaşmazlığı üzerinden Azerbaycan ile Ermenistan'ın yeniden çatışmaya girmeleri ve Azerbaycan'ın önemli başarılar elde etmesi ile gücünün sınırlarına ilişkin yer yer aşırı derecede abartılı anlatımların olduğu Ermeni diasporası faktörünün Ermenistan ile ilişkileri bağlamında yeniden ele alınması gerekliliğini doğurdu. Diğer taraftan bu çalışma, Diaspora Ermenilerinin Ermenistan tarafindan 'sağmal bir inek' olarak görüldükleri algısından kaynaklanan diaspora unsurlarının Ermenistan yöneticilerinden duydukları rahatsızlıkları ve taraflar arasındaki sorunları yok saymamaktadır (Tuncel, 2015, s. 49). Bununla beraber Ermenilerin yoğun olarak diaspora milletlerinden biri haline gelmeye başladıkları tarihlerden bugüne farklı alanlarda ilişkilerin olduğu gerçeğini yansıtma iddiasındadır. Bu kapsamda diaspora Ermenileri ile Ermenistan arasındaki ilişkilere detayları alt başlıklar halinde verilen siyasi, ekonomik ve dini ilişkiler bakımından odaklanılmaktadir.

\section{Siyasi İlişkiler}

Ermeniler, farklı tarihlerde yaptıkları göçlerle diaspora milletlerinden biri haline gelmeye başlamıştır. 7. Yüzyılda İngiltere'de olduğu gibi, zaman zaman ticari kaygılarla göç ettiler (George, 2002, s. 20). Ancak Ermeni diasporasının asıl kitlesi, 1915 y1lı ve sonrasında gerçekleşen göçlerle beraber vücuda geldi. Diaspora Ermenileri ile Ermenistan arasındaki ilişkilerse, Ermenilerin diasporalaşma süreçleri ve 28 Mayıs 1918'de Ermenistan Demokratik Cumhuriyeti'nin Erivan merkezli olarak kurulduğunun ilan edilmesiyle başladı (Bkz: Bournatian, 2011, s. 46-64). Esasen Diaspora Ermenilerinin bir Ermeni devleti kurulmas1 öncesinde, bu amaç doğrultusunda hareket edenlerle iş birliği söz konusudur. 28 Mayıs 1918 'den sonra artık Türklere karşı mücadele yürüten, Ermeni devletini desteklemeye başladılar (Чưnquútuudun' 1948: 147-148). Ancak bu Ermeni devletinin ömrü çok k1sa olmuştur. Bağımsızlığını iki buçuk yıl sürdürebilmiş ve SSCB'nin bünyesine dâhil olarak bağımsızlığını kaybetti. Bu tarih aralığına denk gelen Paris Barış Antlaşması'nın müzakereleri sürecinde, Ermenistan'ın elinin kuvvetlenmesi için Ermenistan'ın yanında yer aldılar. Diğer taraftan 1980'lerin sonlarında Sovyetlerin parçalanma sürecine girmesiyle Eylül 1991'de Ermenistan'ın bağımsızlı̆̆ını ilan etmesine kadar geçen süre zarfında Ermenistan ve Ermeni diasporasını siyaseten birbirlerine yaklaştıran iki önemli gelişme söz konusu oldu. Bu gelişmeler; 1965'te sözde soykırım iddialarının 50.yılı bahanesiyle özellikle de radikal Ermenilerin destek verdikleri ASALA ${ }^{1}$ (Armenian Secret Army for the Liberation of Armenia (Ermenistan'in

\footnotetext{
${ }^{1}$ Sözde Ermeni Soykırımı iddialarının merkezinde yer alan 1915'ten 50 yıl sonra 1965 'e gelindiğinde, radikal Ermeni grupları bu iddiaları kabul ettirmek için Türkiye karşı harekete geçtiler. Bu tarihlerde belirtilen grupların Türkiye ve Türklere duydukları kin ve nefret iyice yoğrulmaya başladı. Bu noktada, Türkiye'nin dış temsilciliklerindeki personellerinin hedef haline getirilmesiyle sonuçlanan yeni bir süreç, ASALA süreci başladı. Türkiye'nin dış temsilciliklerindeki personeller, fikri açıdan terörize olan Ermenilerce katledilmeye başlandı. Bu terör saldırılarından ilki, Gourgen Mıgırdıç Yanıkyan tarafından gerçekleştirildi. Gourgen Mıgırdıç Yanıkyan, öldürebilmek için plan yapmış ve cinayeti işlemiştir. Cinayeti, 1915 olaylarının intikamını almak için tasarladığı ve uyguladığını söyledi. Yanıkyan'ın cinayeti nasıl tasarladığı ve diplomatlarımızın şahadetinden sonra yaşanan süreç için bkz: Bilal N.Şimşir, Şehit Diplomatlarımız, C.1, Ankara: Bilgi Yayınları, 2000, 81-117.
} 
Kurtuluşu için Ermeni Gizli Ordusu)) ile Türkiye'nin yabancı ülkelerdeki personellerine yönelik bir dizi kıyım hareketi başlatılması ve 7 Aralık 1988 tarihinde Ermenistan'da yaşanan depremdir.

Ermeni diasporası ile Ermenistan idarecileri arasında 2008 yılında Türkiye-Ermenistan ilişkilerinde yakınlaşmadan kaynaklanan krizde olduğu gibi çok sayıda çatışma alanı ve türlü anlaşmazlıklar olsa da diaspora Ermenilerinin 1991 yılından itibaren Sözde soykırım iddiaları merkezli olarak Ermenistan'a verdiği siyasi desteği artırdığı görülmektedir (Litter, 2014). IDeA Foundation adlı yapıyı ortaya çıkaran Rusya Ermenilerinden Ruben Vardanyan da 2016 yılı itibariyle diasporadaki Ermeniler ve Ermenistan arasındaki ilişkilerin 25 yıl öncesi ile aynı durumda olmadığını belirterek çeyrek asır içerisinde ilişkilerin seyrinin yönünü belirtmektedir (Şanamyan, 2016). Ermeni diasporası ve Ermenistan ortaklığının gelişmesinde, Eylül 1991'den itibaren Yukarı Karabağ merkezli olarak süren Azeri-Ermeni gerilimi önemli bir dönemeçtir. SSCB'nin bünyesinde bulunan devletlerin birer birer bağımsılılılarını elde etmeleriyle hem Azerbaycan hem de Ermenistan kendi bağımsızlıklarını elde etmişlerdir. Bu süreç beraberinde taraflar arasında sınır ihtilaflarının doğmasına ve Azeri-Ermeni savaşının patlak vermesine neden oldu. Özellikle de Ermeni askerlerinin Hocalı'da yaptıkları katliamla zihinlere yerleşen işgal ile Ermeni güçleri Yukarı Karabă̆'1 işgal etmiştirler. Diaspora Ermenileri, Karabağ sorununu değerlendirirken Azerbaycan'1 Türkiye'nin uydu devleti olarak nitelendirildi. Soykırım suçlaması yaptıkları Türkiye'nin de çatışmanın tarafı olduğu algısı ile meseleye ayrıca önem verildi (Chernobrov ve Wilmers, t.y). Bunun bir yansıması olarak sayıları az olmakla birlikte Diaspora Ermenilerinden bazıları savaş alanında silahlarıyla da yer almaktadır (Panossian, 1998, s. 149-196). Düzenledikleri kampanyalarla gerilimin ilk günlerinden itibaren, Azerbaycan'ın iddialarının aksine, Yukarı Karabağ topraklarının Ermenistan'ın doğal bir parçası olduğu savlarını lobi faaliyetlerinin merkezine aldılar. Ermenistan'ın yalnız olmadığını belirterek maddi ve manevi destekte bulunmak için soydaşlarına çağrıda bulundular. Düzenledikleri yardım kampanyalarına Ermeni asıllıların desteklerini almakla yetinmeyerek yaşadıkları ülkelerdeki diğer halkları da desteğe davet ettirdiler. Lobi kuruluşları, anavatanları için yoğun çaba sarf etmeye başlamıştır. Diasporada faaliyet gösteren lobi kuruluşlarından olan Amerika Ermeni Asamblesi (Armenian Assembly of America (AAA)) amacinı 'Sadece Ermenistan ve Dağlık Karabăg'ı ayakta tutmak değil aynı zamanda geliştirmek' olarak belirledi. Bir diğer lobi kuruluşu olan Ermeni Genel Yardım Birliği'de (Armenian General Benevolent Union (AGBU)) aynı amaca hizmet etti. Ermenistan ve Yukarı Karabağ'da faaliyet gösterebilmek için birer ofis açtılar. Amerika Ermeni Ulusal Komitesi (Armenian National Committee of America (ANCA)) ve Ermeni Asamblesi, Yukarı Karabağ'ın bağımsızlığı ve bölgeye yapılan yardımların artırılması için Amerikan Kongresi'nde yoğun lobi faaliyeti yürüttüler. Diasporadaki Taşnaksutyun (Armenian Revolutionary Federation (ARF)) üyeleri, Yukarı Karabağ'ın Azerbaycan topraklarından ayrılması sürecinde yer aldılar. Taşnaklar, Kaliforniya ve Fransa'dan savaşın cephe boyutuna da destek gönderdiler (Gregg, 2002, s. 2425).

Ermeni diasporası, 2000'li yıllarla propaganda faaliyetlerinin öncülügünde Türkiye'yi uluslararası arenada yalnızlaştırmak için Ermenistan ile siyasi işbirliğini yoğunlaştırmaya başladı. Ermenistan'la ortak hareket etmek kaydıyla Birleşmiş Milletler Ayrımcılığın Önlenmesi ve Azınlıkların Korunması Alt Komisyonu, Avrupa Konseyi, Avrupa Parlamentosu, Dünya Kiliseler Konseyi, İnsan Hakları Derneği gibi uluslararası kuruluşlar nezdinde sözde soykırım iddialarını onaylar nitelikte Arjantin, Almanya, Belçika, Şili, Güney Kıbrıs, Fransa, Litvanya, İtalya, Rusya, Slovakya, İsveç, İsviçre, Vatikan, Venezuela, Hollanda, Lübnan ve ABD’nin 41 eyaletinde kararlar aldırdılar (Yaşın, 2014). Bunun yanı sıra lobi faaliyetleri yürüten kuruluşlardan ANCA, uzun yıllar boyunca Türkiye'nin ABD ile ilişkilerini ve aldığ silah yardımlarını sonlandırmak için çabaladı. İnsan haklarının ihlali söz konusu olduğunda 
silah satışlarının durdurulmasını öngören Çalışma Tüzüğü (Code of Counduct) düzenlemesiyle Türkiye'ye silah satışlarının durdurulması için çalıştı. Türkiye'nin sözde Ermeni soykırımını kabul etmediğini, Ermenistan ve Dağlık Karabağ'a ambargo uyguladığını ve Ermenistan topraklarının bir kısmını hal-i hazırda Türkiye'nin işgali altında olduğunu ileri sürerek bu taleplerde bulunmaktadır. Diğer taraftan Diaspora Ermenileri, Türkiye'nin AB süreci başta olmak üzere lehine olabilecek projelere sekte vurmayı ve zayıflamasını arzu etmektedir (Gregg, 2002: 32-39; Kantarc1, 2007, s. 205-206).

Diaspora Ermenileri, 1915 Olaylarının 100.yılı olan 2015 yılı ve sonrasını, Türkiye'nin sözde soykırım iddialarını kabul ettiği, 1915 Olayları mağdurlarının yakınlarına tazminat ödendiği, Ermenistan'a ait olduğunu ileri sürdüğü toprakları iade ettiği vs. taleplerinin gerçekleştirildiği dönemler olarak hatırlamak istemektedirler. Bu doğrultuda hazırlıklara hız verilerek belirtilen hava içinde Ermeni diasporası ve Ermenistan ilișkileri için Diaspora Bakanlığı adında bir bakanlığında kurulduğu ülkede, 2020 yılının sonlarında Yukarı Karabağ anlaşmazlığı üzerinden Azerbaycan ile Ermenistan'ın yeniden çatışmaya girmeleri ve Azerbaycan'ın önemli başarılar elde etmesi ile gücünün sınırlarına ilişkin yer yer aşırı derecede abartıların olduğu Ermeni diasporasına ilişkin sorgulamaları da beraberinde getirdi. Nitekim Diaspora Ermenilerinin yoğun olarak yaşadıkları Fransa'da yaptıkları bütün girişimlere rağmen Fransız hükümetinin gelişmelere müdahale etme noktasındaki isteksizliği de Ermeni diasporasının gücünün tartışma konusu olmasına neden oldu (DW, 2020). Sürecin büyük oranda Azerbaycan'ın başarısı ile neticelenmesi ise, 'Karabağ'ı Tanı' sloganıla Diaspora Ermenilerinin verdiği destekler ile yürütülen Yukarı Karabağ topraklarının Ermenistan'ın parçası olduğu tezinin de istenilen hedefe ulaşamadığının göstergesi oldu (Cheterian, 2021).

\section{Ekonomik İlişkiler}

Diaspora Ermenileri, tarihi süreç içinde göçlerin yoğunlaşmasıyla birlikte ekonomik anlamda güçlenmişlerdir. Göç edenler, geride bıraktıklarına gönderdikleri maddi yardımlarla taraflar arasında ilişkilerin kurulmasını sağladı. Örneğin, Osmanlı topraklarından 1915'e kadar Yeni Dünya'ya (Amerika kıtasına) göç edenlerin cinsiyetleri ağırlıklı olarak erkeklerdir. Bu kişiler geride ailelerini bırakıp Diaspora Ermenilerinin ilk nüvelerini oluşturdular. Yerleştikleri ülkelerde iş hayatına atılıp mevcut şartlarını iyileştirmek için gayret sarf etmiştirler. Anadolu'da bulunan ailelerine para göndermeye çalıştılar. İlk göçmenler, göç edeceklere de destekte bulundular. Bu göçmen Ermeniler yerleşimlerini sürdürürlerken ülkeye yeni göç eden kişi ya da kişilere hem maddi hem de manevi anlamda destek olmak için çalıştılar. Bu sayede göç edenlerin uyum sorunlarını daha kolay aşmalarına katkı sundular (Akter, 2007, s. 111-116). Amerika'ya yerleşen göçmenler, geride bıraktıkları yakınlarını getirmeleri için buharlı gemi kumpanyalarının bilet satış acenteliğini bile aldılar (Kara, 2020, s. 205).

Diaspora Ermenilerinin soydaşlarına ekonomik destekleri bağlamında Brezilya'ya yerleşen Ermenileri de ele almak mümkündür. Brezilya'daki Ermeni cemaatinin ilk yardımları, aynı zamanda ilk faaliyetleri, Harput kökenli Vahe Bogosyan öncülüğünde, Ermeni Kızılhaç'1 adlı derneği kurmalarıyla birlikte gerçeklești. Sao Paulo'da kurulmuş olan birliğin veznedarı olan Vrtanes Kepenliyan, toplanan 10.924.75 Fransız Frangını parça parça Paris'e, 1919'da Paris Ermeni Ulusal Delegasyonu Başkanı sıfatıyla görev yapan Bogos Nubar'a, gönderdi. Yapılan yardım toplamda 10.924.75 Fransız Frangı buldu.

Tablo 1: Büyük bir ermeni devletine ulaşmak için çabalayan Bogos Nubar'a gönderilen yardımlar

\begin{tabular}{|l|l|l|}
\hline Y11 & İngiliz Altın1 & Fransız Frang1 \\
\hline 6 Kasım 1915 & 12 & 300.50 \\
\hline 30 Kasım 1915 & 25 & 690.00 \\
\hline 3 Ocak 1916 & 30 & 829.50 \\
\hline
\end{tabular}




\begin{tabular}{|l|l|l|}
\hline 18 Şubat 1916 & 20 & 558.00 \\
\hline 31 Mart 1916 & 16 & 453.75 \\
\hline 4 Ağustos 1916 & $243.2,6$ & $6.139,00$ \\
\hline 14 Kasım 1916 & 20 & 554.00 \\
\hline 20 Mart 1917 & 20 & 470.00 \\
\hline Toplam: & 383.2 .6 & 10.024 .75$. \\
\hline
\end{tabular}

Kaynak: Ч.upnufituu氏̨, 1948, 49-50.

Brezilya topraklarında, Sao Paulo merkezli, Ermeni cemaati tarafından kurulan bir diğer dernek olan Ermeni Hayırseverler Birliği de farklı tarihlerde ekonomik yardımlarda bulundu. Derneğin başkanı, Suriye kökenli zengin Ermenilerden Elya Nakkaş'tı. Elya Nakkaş, farklı tarihlerde Bogos Nubar'a 25.275.00 Fransız Frang1 gönderdi. Bogos Nubar'a iletilen yardımlar, cevaben gönderilen teşekkür mektuplarıyla karşı1ık buldu. Bu kapsamda belirtilen tutardaki yardıma karşılık, Bogos Nubar'ın imzasının yer aldığı bir teşekkür mektubu Elya Nakkaş'a gönderildi. 9 Nisan 1918 tarihli bir telgrafta da 200 İngiliz altını (5.428.00 Fransız Frang1) Sao Paulo Ermeni Hayırseverler Birliği tarafından Bogos Nubar'a gönderilmiştir. Bogos Nubar, bu telgrafa 6 Haziran 1918'de cevap verildi. Nubar, 'Londra- Brezilya bankalar birliğiyle Kafkas Ordusu Ermeni Askerleri için gönderdiğiniz 200 Ingiliz altını, 5.428.00 Fransız Frank'tır. Gönderdiğiniz miktar istediğiniz işler için kullanılacaktır.' Bogos Nubar, 'en kalbi

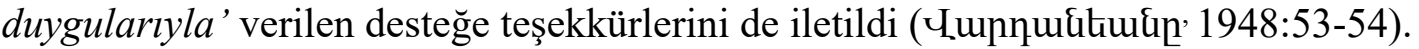

Brezilya'daki Ermeni cemaatinin, Ermenistan'a verdiği desteği gösterir mahiyetteki yardımları 1919'da da devam etti. Bu doğrultuda 24 Mart 1919'da her biri 1.000 Frank olan iki çek Bogos Nubar'a gönderildi. Elya Nakkaş, 23 Ekim 1919'da yeni bir yardım iletildi. Yardıma ilişkin iletilen mektuptan tutarın 10.000 Fransız Frangı olduğu anlaşılmaktadır. Bogos Nubar, mektubu 5 Aralık'ta şu ifadelere yer vererek cevapladı:

23 Ekim tarihinde göndermiş olduğunuz mektubunuz geldi. Brezilya, Fransız-İtalyan bankaları aracılığıyla göndermiş olduğunuz 10.000 Fransız Frangını almış bulunuyorum... Millet olarak verilen destekten, Kafkasya ve Ermenistan'ın yardım çığlıklarının dört bir taraftan duyulmasından ve yardım edilmesinden dolayı son derece minnettarız. (Uumnudituunp' 1948:57-58).

Ermenilere yapılan yardımlardan bir diğeri, 17 Kasım 1920'de gerçekleşti. Bu tarihte Bogos Nubar'a, 5 bin Franklık bir çek gönderildi (Uuunuưtuuup' 1948: 63). Brezilya'daki Ermeni diasporasının ilk nüveleri, Ermeni Kızılhaç'ına ve Ermeni Hayırseverler Birliği'ne yardımlarıyla destek oldular. Bunun yanı sıra ülkede faaliyet gösteren Ermeni birlikleri arasında yer alan Presidente Altino Ermeni Birliği de kapanma ihtimali durumda ellerindeki varlıkların

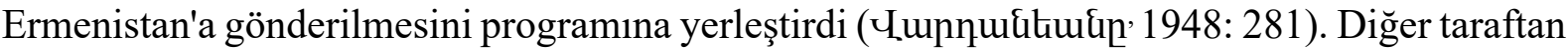
diasporadaki Ermeniler faaliyette bulundukları yerlerde diğer Ermenilere mali destek oluştururken kendi cemaatlerinin zenginlerine de baskı kurdular. Osmanlı arşivinde yer alan 1893 tarihli bir belgede Paris'te Ermenilerin zengin Ermenileri tehdit ederek para topladıkları iddiasının araştırılması gerektiğine yer verildi (COA, HRS. SYS, Dosya No: 2748, Gömlek No: 18, Tarih: M.18.09.1893). Yine Osmanlı arşivinde diasporadaki Ermenilerin diğer Ermenilere yaptıkları yardımlar pek çok belgede konu edinildi. 'Vilayet-i Şahane'deki Ermenilere akçe tevzi eylemek üzere' şeklinde giriş yapılan 1913 tarihli bir diğer belgede, İstanbul'da bulunan Ermeni Patriği, kendilerine çok kötü muameleler yapıldığını iddia ederek Osmanlı Devleti'nin hasımlarından olan Doverstır Patriği Deronyan'dan Amerika'daki Ermenilerden yardım etmeleri talebinde bulundu. Deronyan, İstanbul'dan gelen mektubu ayin yaptıkları bir sirada okudu ve yardım isteğini hazır bulunanlara iletti. Bu ve benzeri pek çok talep, Diaspora Ermenilerinin maddi desteklerine neden oldu (COA, A.MKT. MHM, Dosya No: 688, Gömlek 
No: 9, Tarih: H.08.10.1313 (15.03.1896)). Amerika'daki Ermeniler tarafindan toplanan paraların bir Amerikalı tarafından Adana' da dağıtılmakta olduğu bilgisi de verildi (COA, HRS. ŞFR, Dosya No: 512, Gömlek No: 41, Tarih: H.24.12.1331 (24.11.1913)).

Ermeni diasporasının soydaşlarına en ciddi yardımlarından biri, 7 Aralık 1988 tarihinde Ermenistan'da yaşanan 7,2 şiddetindeki deprem sırasında gerçekleşti. Gümrü ya da Spitak depremi sonrasında, 20.000'in üzerinde insan hayatını kaybetti, depremin yaşandığ bölgelerdeki devlet kurumları ciddi anlamda hasar gördü (Verluise, 1995). Deprem sonrasında, Türkiye'nin de aralarında bulunduğu, pek çok devlet Ermenistan'ın yaralarını sarmak için yardım eli uzattı. Ermenistan Merkez Bankası Başkanı'na göre, 1996 yılı bütçe gelirleri 237 milyon dolar ve bütçe giderleri 370 milyon dolar olan ülkeye yalnızca 1995 yılında 100 milyon dolar yardım gönderildi (Panossian, 1998, s. 149-196). Bu yardımlar için Diaspora Ermenileri, Ermenistan'a yardım yapılması çağrılarında bulundular ve kampanyalar düzenlediler. Ermeni Genel Yardım Birliği'nin (Armenian General Benevolent Union (AGBU)) girişimleri ve katk1lariyla, Amerika Ermeni Asamblesi (Armenian Assembly of America (AAA)), Amerika Ermeni Misyoner Birliği (The Armenian Missionary Association of America (AMAA)), Ermeni Yardım Topluluğu (The Armenian Relief Society (ARF)), Amerika Ermeni Kilisesi Piskoposluğu (The Diocese of the Armenian Church of America), Amerika Apostolik Ermeni Kilisesi Piskoposluğu (The Prelacy of the Armenian Apostolic Church of America) ve Lincy Kurumu'nun (The Lincy Foundation) bir araya gelmesiyle Birleşik Ermeni Fonu'nu (United Armenian Fund (UAF)) oluşturdular. Bu fonla belirtilen yapılar, Ermenistan'a 500 milyon dolar gibi bir yardımda bulundular. Diasporada varlıklarını sürdüren Taşnak, Hınçak ve Ramgavar Partileri de Ermenistan'a yardıma koştular. Ermenistan'da yaşanan depremde yaraları sarmak için harekete geçen oluşumlardan biri de Bütün Ermenistan Fonu'dur (The All Armenia Fund). Ermenistan merkezli faaliyet gösteren fonun, 32 ülkede şubesi vardır. 2006 yılına kadar ki süreçte 165 milyon doları aşan yardım toplanıldı (Gyulumyan'2008). 1988 depremi sonrasında yürütülen lobi faaliyetleriyle de ABD'nin Ermenistan'a yardımları yıllık yaklaşık 90.000.000 doları buldu. 1999'da Amerikan Kongresi, ülkeye yapılan yardımların 75.000.000 dolara indirilmesini tartışsa da Ermeni lobilerinin gayretleriyle bu tartışma rakamın aşağı doğru revize edilmesinin engellenmesiyle sonuçlandı. Lobi, kuruluşları bir taraftan Amerikan yönetim organları üzerinde bir baskı mekanizması olarak faaliyet icra ederken diğer taraftan da halkın Ermenistan'a ve Yukarı Karabağ'a yardım yapması için bölgeye dikkat çekmeye çalıştılar (Gregg, 2002, s. 32-39; Kantarc1, 2007, s. 200).

Ermenistan'ın SSCB'nin dağılmasıyla bağımsızlığını elde etmesinin ardından başlattığ ekonomik kalkınma hamlesinde de Diaspora Ermenilerinin katkısı oldu. Ermenistan, Diaspora Ermenilerinin desteği ile 2005 ve 2006 yıllarına gelindiğinde, \%10 civarındaki Gayrı Safı Milli Hasılasını \%13-\%14 yükseltti. Yine ülkedeki yoksulluk oran1, \%55'lerin üzerindeyken \%30'lara kadar indi ve 1999-2004 yılları arasında dünyanın en hızlı büyüyen devletlerinden biri haline geldi (Chakhalyan, 2007, s. 32-33). Diaspora Ermenilerinin Ermenistan'a verdikleri desteği ekonomik açıdan gösteren yardımlar çerçevesinde Ermeni Asamblesi, Işık Kaynağı Partiküleri Artırıcısı Projesi için başlangıç olarak 15.000.000 dolarlık kredi verdi. AGBU ise, Erivan'da bulunan Ermenistan Amerikan Üniversitesi için 9.000.000 dolarlık yardımda bulunarak ülkeyi kalkındırmaya çalıştı (Gregg, 2002, s. 37; Kantarc1, 2007, s. 200-201).

Ermeni diasporası, Ermenistan'a doğrudan ya da dolaylı olarak ekonomik yardımlar yapmakla yetinmedi. Azerbaycan aleyhinde lobi faaliyeti yürüterek Azerbaycan'1 zayıflatmak için kararlar da aldırmaya çalışarak Ermenistan'ın bölgedeki rakibini geçmesi için çabaladı. Bu kapsamda 1992'de SSCB'den ayrılan ve bağımsızlıklarını elde eden devletlere Amerika'nın teknik ve finansal yardımını öngören Bağımsızlığ Act) karşı yürüttükleri lobi faaliyeti sonucunda, Madde 907'yi (Section 907) eklettirerek Madde 907 Bağımsızlığı Destekleme Kanunu (Section 907 Freedom Support Act) adını alan yasayı 
kongreden geçirildi. Ermeni diasporasının tarihi bir zafer olarak benimsediği bu kanunla 1992'den 2001'e kadar Amerika'nın Azerbaycan'a teknik ve finansal yardımın kısıtlamasına neden olundu. Türkiye'nin başını çektiği, 14 petrol şirketi ve İsrail lobisiyle yürütülen karşı lobi faaliyetine rağmen bu madde 2001 y1lına kadar yürürlükte kaldı (Gregg, 2002, s. 33-34; Kantarc1, 2007, s. 200-201). Ayrıca 1998 yılında, Ermeni diasporasının Ermenistan'a ekonomik işbirliği çerçevesinde neler yapılabileceğinin üzerinde de duruldu. Farklı ülkelerden gelen Ermenilerin katıldıkları diaspora toplantıları yapıldı. Diaspora unsurları, on dördüncü büyük çaplı organizasyonlarıyla toplamda yaklaşık olarak 900,000 dolar Ermenistan'a gönderilmiştir. Başta ABD olmak üzere yabancı devletlerle Ermenilere ait olmayan organizasyonların yardımları ile Ermenistan'ın bağımsızlığından 2004 yılına değin 1.493.760.000 dolarlık malzeme desteğinde bulunuldu (Manaseryan, 2004, s. 1-22). Diaspora Ermenileri 2020 yılına değin, Ermenistan ve Dağlık Karabağ'ın kalkındırılması için büyük gayretler sarf etti. Ülkedeki sosyal ve kültürel hizmetlerin gelişmesi, okulların yenilenmesi, yolların bakımlarının sağlanması gibi farklı alanlarda milyon dolar katkıda bulundu. Bakü, Gence ve Sumgayıt gibi yerlerdeki Ermenilerin yerleşimleri için de parasal destek verdi. Diaspora Ermenilerinin ne kadar para verdikleri tam olarak bilinmese de Ermenistan Fonu ile Ermenistan ve Karabağ'daki farklı projelere geçen on yıl zarfında 100 milyon doların üstünde yatırım yapıldı (Cheterian, 2021).

Ermenistan ve Diaspora Ermenileri tarafından Ermenistan'ın dışında yaşayanların ülke ile gönül bağları oluşturarak ülkenin ekonomik olarak canlandırılması için farklı organizasyonlar da gerçekleştirilmektedir. Bu çerçevede Diaspora Bakanlığı'nın 2009 yılında başlattığı Ari Tun (Eve Gel) projesi, Diaspora Ermenileri ile Ermenistan yakınlaşması için önemli adımdır. Proje kapsamında 2016 yılında Ermenistan dışından gelen 162 kişi 128 Ermeni hanesine yerleştirildi (ArmInfo, 2016). Ermenistan'a diaspora örgütlerinin organize ettiği gezilerde diaspora Ermenileri ile Ermenistan arasında duygusal köprülerin inşasının yanında ekonomik açıdan da ülkeye girdiler sağlamaktadır (Piligian, 2021).

\section{Dini İlişkiler}

Dünya üzerinde varlık göstermiş ve gösteren bütün mezhepler, tarikatlar, etnik yapılanmalar, siyasi oluşumlar vb. hareketler kendilerini faaliyette bulundukları alanların öncülerine bağlarlar. Bütün bu yapılar, böylece kendi hareketlerinin meşruluğunun tartışma dışında bırakılmasını hedefler. Hıristiyan dünyası da bu durumun dışında değildir. Hıristiyan dünyasında ortaya çıkan her hareket, kendini Hz. İsa ve Havarilerine bağlamaya çalışmaktadır. Ermeniler, Hıristiyan dünyasının bir mensubu olarak, Gregoryen Ermeni Kilisenin, Havarilerce inşa edildiğini savunarak belirtilen gayretin içinde yerlerini alırlar. Ermeniler iddialarını, Havarilerden Taddeus'un M.S. 35-43 ve Bartolomeus'un M.S. 44-60 yilları arasinda Ermenistan'da görev yaptıklarına dayandırırlar. Bu iddia ile beraber Ermeniler, Ermeni kilisesinin Apolostik (Havarilere ait) kilise olarak kabul görmesini hedeflemektedirler. $\mathrm{Bu}$ iddianın yanı sıra Hıristiyan milletler arasında itibarlarını artıracak Hıristiyanlığı toptan kabul eden ilk millet oldukları savı da önemlidir (Kaloustian, 1969, s. 89-92; Küçük, t.y, s. 117-127).

Ermenilerin Eçmiyazin Ermeni Kilisesi üzerindeki bu iddiaları, güçlü mezhep vurgusuyla bütün soydaşların aynı mezhep dairesinde kalmasını temine de yöneliktir. Buna rağmen Ermeniler, tarihi süreç içinde mezhepsel anlamda birbirlerinden ayrıldılar. Bu süreçte İngiltere, Fransa ve Rusya'nın başını çektiği Batılı devletlerin izledikleri politikalar etkili olmuştur. Bu devletler, Osmanlı Devleti'nin 17. yüzyılın başlarından itibaren gitgide eski gücünü kaybetmesiyle yeniden gün yüzüne çıkan Şark Meselesi ve 1789'daki Fransız İhtilâli ve sonrasında ortaya çıkan milliyetçilik akımının etkisiyle özellikle de çok uluslu yapıların parçalanma evresine girmesini avantaja çevirmek istediler (Kodaman, 2001, s. 22- 33). Bu niyetle Osmanlı Devleti'ni doğrudan baskı altına almalarını sağlayacak enstrümanları ve 
ellerindeki bu amaç doğrultusunda kullanacakları tali unsurları devreye soktular. Ermenileri, Osmanlı Devleti'ni parçalamak için kullanacakları tali unsurlardan biri olarak görüştüler. Emperyal niyetleri olan her bir Batılı devlet Ermenileri kendileri taraflarına kazanmak maksadıyla Ermeni milletinin arkasında oldukları izlenimini oluşturmaya ve Ermeniler için bir devlet kurulması fikrinin zihni alt yapısını hazırlamaya çalıştılar. Osmanlı coğrafyasında, her bir Batılı devlet kendi ülkesinin okullarının açılması için misyonerlik faaliyetlerine destek verdiler. Osmanlı Devleti'ne karşı yaptırımlar kullanmaktan da geri durulmayan bu süreç sonrasında Ermeniler mezhepsel anlamda da birbirlerinden farklılaştılar. Protestanlığın hamiliğini, İngiltere ve ABD; Katolikliğin hamiliğini, Fransa ve Almanya; Ortodoksluğun hamiliğini, Rusya üstlendi. Bunun neticesinde Ermenilerden de Protestan ve Katolikler ortaya çıtı (Uras, 1987, s. 419-437).

Diaspora Ermenileri, bulundukları ülkelerde dini vazifelerini yerine getirmelerini sağlayacak ibadethanelerini kurdular. Dünya Ermenileri nazarında, en kıymetli ibadethanelerin başında Ermenistan'da bulunan Ecmiyazin kilisesi ve Lübnan'da bulunan Antilyas kiliseleri gelmektedir. Bunlardan Ecmiyazin kilisesi'nin önemini ve inşasının ortaya çıkışı ele alacak olursak; Ecmiyazin kelimesi, 'Tanrının biricik oğlunun indiği yer' anlamına gelir. Rivayete göre Aziz Gregory, Ermeni kralı ve bütün ülkesini Hıristiyanlaştırdıktan sonra bir gece, Ermeni krallığının başkentinde ilk ibadethane olarak inşa etmeyi düşündüğü kilisenin şekli ve yeri hakkında derin bir tefekküre dalmışken şöyle bir hayal görür:

Gök yarılmış, yeryüzünü parlak bir ışık kapladı. Gökten inen bir 1şık hüzmesi içinde meleklerin bir alayı yeryüzüne inmeye başladı. Bu semavi grubun başında uzun boylu ve muhteşem yüzlü birisi vardı. O, Tanrı'nın Oğlu olarak doğmuş olan İsa'nın kendisiydi. Elinde altın bir çekiç tutmaktaydı. Gökten yere doğru inerken, şimdiki Ecmiyazin Kilisesi'nin bulunduğu yere üç kere vurdu. $\mathrm{O}$ anda yerden altın bir sütun yükselmiş, sonra mükemmel bir kilise haline dönüştü. Hayal kaybolmadan önce, bu kilisenin hatları ve şekli silinmez bir şekilde aziz Gregory'in zihnine yerleşti. (Kaloustian, 1969, s. 92-93; Küçük, t.y, s. 121).

Antilyas kilise ise; Kozan'da (Sis) bulunan Gregoryen Kilisesi'nin, 1921'de Kozan'dan ayrilarak, önce Adana'ya nakledildi. Adana'dan da Halep'e, 1929'da da Beyrut'un Antilyas semtindeki binasına taşındı. Kilise, ortaçağdaki Kilikya (Sis Kilisesi) adını değiştirdi. Beyrut'a yerleşmesinden sonraki ilk zamanlarda, kilisenin yetki sahası Beyrut, Suriye'de Şam, Halep ve Lefkoşa ile sınırlı olmasına rağmen, 1956'dan sonra Yunanistan Atina, İran, New York ve Kuveyt'e kadar genişledi (İlter, 2001, s. 115-125). Diaspora Ermenileri, bulundukları ülkelerde kendi ibadethanelerini vücuda getirdiler. Kurdukları ibadethanelerin temellerinin dayanak noktalarından ikisi, Ecmiyazin ve Antilyas kiliseleri oldu. Brezilya'daki ilk Ermeni ibadethanesinin kuruluşu, hem bu merkezlerden birine bağlıyken göç eden bir din adamının üstlenerek kurulması hem de kurucularının göç deneyimlerini yansıtması bakımından kıymetlidir. Brezilya'daki Ermeni cemaatinin kendi kiliselerini inşa sürecinin temelleri, 1922'de Konya'daki Ermeni koleji öğrencilerinden, aslen Ispartalı olan George Samuelyan adından bir genç Ermeni'nin Sao Paulo'ya göç etmesi ve kardeşini Brezilya'ya davet etmesiyle birlikte atılmıştır. Bu tarihlerde Sao Paulo'da Ermeni kilisesi olmadı̆̆ gibi Ermeni cemaatine dini liderlik yapacak kimse de yoktu. George Samuelyan, Halep'te bulunan kardeşi Gabriel Samuelyan'a bir mektup göndermiştir ve kardeşini Sao Paulo'ya çağırdı. Gabriel Samuelyan, Kilikya Ermeni Katogikosluğu'na bağlı olarak dini vazife yapan bir Ermeni ruhanisiydi. Gabriel Samuelyan, Halep'ten Brezilya'ya gidebilmek için öncelikle ülkenin Halep konsolosluğundan onay almaya çalışmıştır; ancak gerekli izni alamadı. Gabriel Samuelyen ve ailesi nihayet 10 Haziran 1923'te kaçak olarak çıktıkları gemi yolculuğuyla Santos'a ulaştılar. Santos'tan Sao Paulo'ya gelişi de kardeşinin girişimiyle oldu. George Samuelyen, Manuk Körükyan'in oğlu Karabet Körükyan'la birlikte Santos'a, Gabriel Samuelyan'ın yanına gittiler. Santos'dan Sao Paulo'ya giden bir gemiyle, Gabriel Samuelyan ve ailesini Sao Paulo'ya getirdiler. Gabriel Samuelyan, ülkeye geldiği ilk zamanlarda Brezilya'daki Ermeni yetimlerine ve ihtiyaç 
sahiplerine yardım çalışmalarına katıldı. George Samuelyan, Kardeşi Gabriel Samuelyan'ın Sao Paulo'ya gelmesiyle, burada yaşayan Ermeni cemaati arasında daha etkin bir mevkiye geldi. Nitekim George Samuelyan'ın etkinliği, kardeşi Gabriel Samuelyan'ın 25 Temmuz 1923 'te Anthony de Mello sokağı 34 numaradaki Harputlu Melkon Kalaycıyan'ın evinde yapılan toplantıda Ermeni cemaatinin yardım işlerini organize etmesine ve Ermeni cemaati için inşa edilecek kilisenin de kuruculuğunu üstlenmesine karar verilmesini sağladı. Gabriel Samulyan'ın

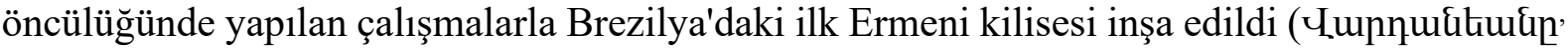
1948:74).

Diaspora Ermenileri, zaman zaman Ecmiyazin'e ziyaretler düzenleyerek de dini açıdan Ermenistan'la bağlantılarını sürdürmektedirler. Bu kapsamda 2014 yılında Ermenistan ile Ermeni diasporasının bağlarını güçlendirmeye çalışan Ermeni Genel Yardım Birliği'nin Başkanı Berge Setrakyan'ın 13-19 Aralık 2014'te ülkeye yaptığı ziyarette Eçmiyazin'i de ziyaret etti. Ziyaret esnasında, Eçmiyazin kilisesi katogikosu, bay ve bayan Setrakyan'ın kiliseye bağışları ve vatanperver gayretlerinden ötürü memnuniyetini bildirdi (AGBU, 2014). Ermenistan'a Hristiyan Genç Misyonu (Christian Youth Mission to Armenia) örneğinde görüleceği üzere önemli duraklardan biri Eçmiyazin kilisesi olmak üzere Ermenistan'a Diaspora Ermenilerin götürülmesi organizasyonları yapılmaktadır (Tuncel, 2015, s. 145-146).

\section{Sonuç}

Ermeniler, tarihi süreç içinde yaptıkları göçlerle diaspora milletlerinden biri haline geldiler. Osmanlı Devleti'nin son yıllarında hız kazanan göçlerle yerleştikleri yeni yaşam alanlarında varlıklarını sürdürmeye çalıştılar. 1918'de müstakil bir Ermeni devleti inşa eden soydaşları ile günümüze kadar farklı yoğunluklarda ilişkilere sahip oldular. Diaspora Ermenileri, Ermenistan idarecilerince yer yer 'sağmal inek' olarak görüldüklerine dair nitelendirmelerden rahatsızlık duysalar da ülke ile ilişkilerini geliştirerek sürdürdüler. Taraflar arasındaki ilişkilerin sürekliliğini sağlayan en önemli faktör ise, Osmanlı Devleti'nin son dönemlerinde yaşanan hadiseler oldu. Diaspora Ermenileri, merkezine 1915 Olaylarını alarak asimetrik bir biçimde milletlerine karşı soykırım uygulandığı tezini işlemektedirler. Ermeni devletinin idarecilerinin de belirtilen tezi savunmaları ikili arasındaki bağların kuvvetlenmesini sağlamaktadır. 1988 yılında Ermenistan'da yaşanan deprem ve SSCB'nin dağılması sonrasında ortaya çıkan Azeri-Ermeni çatışması ise, ilişkilerin daha belirgin bir biçimde kuvvetlenmesine neden oldu. Bu tarihlerden sonra Diaspora Ermenileri düzenledikleri çeşitli kampanyalarla 1915 Olaylarına ve Yukarı Karabağ'a ilișkin Ermeni tezlerinin uluslararası arenada kabul görmesi için çabalarını artırarak siyaseten Ermenistan'ın yanında oldular. Ermenistan'a desteklerini yıllar içinde artırarak ekonomik olarak Ermenistan'ın güçlenmesini sağlamaya çalıştılar. Eçmiyazin'in önemli rotalardan olduğu gezileri vasıtasıyla Ermenistan ile dini açıdan da irtibatlarını sürdürdüler.

\section{Kaynakça}

\section{Arşiv Belgeleri}

Cumhurbaşkanlığ 1 Osmanlı Arşivi (COA), A.MKT. MHM, Dosya No: 688, Gömlek No: 9, Tarih: H.08.10.1313 (15.03.1896).

Cumhurbaşkanlığ 1 Osmanlı Arşivi (COA), HRS. SYS, Dosya No: 2748, Gömlek No: 18, Tarih: M.18.09.1893.

Cumhurbaşkanlığ Osmanlı Arşivi (COA), HRS. ŞFR, Dosya No: 512, Gömlek No: 41, Tarih: H.24.12.1331 (24.11.1913).

\section{Araştırma ve İnceleme Eserleri}

Akter, A., (2007). Tehcir öncesi Anadolu'dan Amerika'ya (1834-1915), İstanbul: IQ Kültür Sanat Yayınları. 
Alajaji, S. A, (2019). Silaya giden yol Ermeni diasporasinda müzik, İstanbul: Aras Yayınları.

Aslanian, S. D., (2011). From the Indian Ocean to the Mediterranean: The global trade networks of Armenian merchants from New Julfa, University of California Press.

Bakalian, A., (1993). Armenian Americans from being to feeling Armenian, New Jersey: Transaction Publishers.

Basmaciyan, G., (2009). Ermeni modern tarihi ve Ermeni sürgünleri, İstanbul: Pırgic Yayınları.

Barsoumian, H.L., (2013). İstanbul'un Ermeni amiralar sınıfı, İstanbul: Aras Yayınları.

Chernobrov, D. ve Wilmers. L. diaspora identity and a new generation: Armenian diaspora youth on the genocide and the Karabakh War, The University of Sheffield, 1-23.

George, J., (2002). Merchants in exile the Armenian in Manchester England, Taderon Press, $1835-1935$.

Gregg, H.S. (2002), Divided they conquer: The Success of Armenian Ethnic Lobbies in the United States.

İlter, E., (2001). Lübnan'da Ermeni diasporası, Ermeni Araştırmaları, Sayl: 3, 115-125.

Kaloustian, S., (1969). Saints and Sacrament of the Armenian Church, USA.

Kantarcı, Ş., (2007). Amerika Birleşik Devletleri'nde Ermeniler ve Ermeni Lobisi. Ankara: Lalezar Kitabevi.

Kara, A., (2020).Yeni kıtaya Osmanlı göçleri ve neticeleri, Ankara: Platunus Publishing.

Kodaman, B., (2001). Ermeni macerası tarihi ve siyasi bir değerlendirme, Isparta: Süleyman Demirel Üniversitesi Rektörlüğü Yayınları.

Küçük, A. Gregoryen Ermeni Kilisesi'nin oluşması ve konsil kararları karşısındaki tutumu, http://dergiler.ankara.edu.tr/dergiler/37/780/9996.pdf: s.117-127.

Manaseryan, T. (2004 ), Diaspora the comparative advantage for Armenia, Armenian International Policy Research Group, 1-22.

Özocak, Ö., (2014). Diaspora kavramı ve Ermeni diasporas1, YTSAM Ermeni Meselesi Özel Sayısı, 5, 3483-3493.

Panossian, R., (1998). Between ambivalence and instrusiin: Politics and identity in Armeniadiaspora relations, Diaspora: A Journal of Transnational Studies, Vol. 7, N. 2, 149-196.

Şimşir, B. N., (2000). Şehit diplomatlarımız, C.1, Ankara: Bilgi Yayınları.

Tuncel, T. K., (2015). Armenian diaspora, Ankara: Terazi Publishing.

Uras, E., (1987). Tarihte Ermeniler ve Ermeni meselesi, İstanbul: Belge Yayınları.

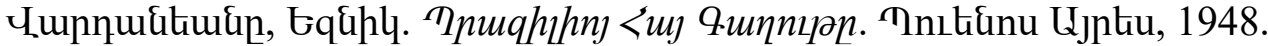

Verluise, P., (1995). Armenia in crisis: the 1988 earthquake, Wayne State University Press, Detroit.

\section{İnternet Kaynakları}

Amerika Ermeni Asamblesi (Armenian Assembly of America (AAA) İnternet Sitesi, (22.06.2021). http://armenian-asembly.org.

Amerika Ermeni Ulusal Komitesi (Armenian National Committee of America (ANCA) İnternet Sitesi, (22.06.2021). http://www.anca.org/.

Armenians in France Plead for Nagorno-Karabakh Intervention, (22.10.2020). DW, https://www.dw.com/en/armenians-in-france-plead-for-nagorno-karabakhintervention/a-55335674.

Cheterian, V., (08.04.2021). Diaspora-Armenia Relations: Are we ready for a serious discussion?,The Armenian Mirror-Spectator, https://mirrorspectator.com/2021/04/08/diaspora-armenia-relations-are-we-ready-fora-serious-discussion/. 
Diaspora Ministry receives 162 Armenians from Diaspora under 'Ari Tun' Project, (24.08.2016). ArmInfo, Diaspora Ministry receives 162 Armenians from Diaspora under 'Ari Tun Project'.

Emin, G., (13.07.2014). We, The Armenian Weekly, https://armenianweekly.com/2012/06/13/gevorg-emin-we/.

Ermenistan Cumhurbaşkanlığı Resmi Sitesi, (22.06.2021). http://www.president.am/en/.

Ermenistan Futbol Federasyonu Resmi İnternet Sitesi, (22.06.2021). http://www.ffa.am/en/home.

Litter, L. (10.07.2014). Armenian Identity in the Diaspora: Between Modernity and Preservation. Repair, https://repairfuture.net/index.php/en/identity-standpoint-ofarmenian-diaspora/armenian-identity-in-the-diaspora-between-modernity-andpreservation-armenian.

Piligian, S. (21.01.2021)._Armenia and the Diaspora: It's All About People and Relationships, The Armenian Weekly, https://armenianweekly.com/2021/01/21/armenia-and-thediaspora-its-all-about-people-and-relationships/.

Sanamyan, E., (14.11.2016). The Armenian Diaspora and Armenia: A New Relationship?, Eurasianet, https://eurasianet.org/the-armenian-diaspora-and-armenia-a-newrelationship.

Yaşın, G.K., (26.04.2017 ). Ermeni İddialarını Kabul Eden Ülkeler. 21. Yüzyıl Enstitüsü, https://21yyte.org/tr/merkezler/bolgesel-arastirma-merkezleri/balkanlar-ve-kibrisarastirmalari-merkezi/ermeni-iddialarini-kabul-eden-ulkeler. 